\title{
A Faction Acclamation Incised on a Pithos Found Near the North-West Church at Hippos (Sussita)
}

\author{
AdAM ŁAJTAR, JOLANTA MlynARCZYK
}

\begin{abstract}
In one of the domestic rooms attached to the North-West Church at Hippos (Sussita), at least three ceramic pithoi were found, all of them in secondary use, possibly for the processing (storing?) of lime. One of them bore an inscription in Greek, scratched into its surface, which turned out to be an acclamation for the circus faction of the Blues. This interesting addition to the corpus of the factions' inscriptions from Syro-Palestine is also lending the dating to the original period of the pithos' use, which cannot be later than the Islamic conquest of the region in $\mathrm{AD} 636 / 638$.
\end{abstract}

Keywords: circus factions, inscription, ceramic pithos, Hippos-Sussita, late Roman period, Byzantine period, early Islamic period, Syro-Palestine

Adam Łajtar, Institute of Archaeology, University of Warsaw, Warszawa; a.f.lajtar@uw.edu.pl

Jolanta Młynarczyk, Institute of Archaeology, University of Warsaw, Warszawa; susyam@wp.pl

In the framework of the exploration project of the North-West Church (NWC) compound in Hippos (Susita, Sussita), ${ }^{1}$ two final field seasons (2007-2008) were devoted, among other things, to the unearthing of the area outside the northern entrance to the atrium. ${ }^{2}$ The entrance in question was reached by two basalt steps leading from a passage (L2543) with a simple earthen flooring (F708). ${ }^{3}$ The passage, c. $3.30 \mathrm{~m}$ wide, was flanked by two rooms of a domestic character: room L2577 (containing three ceramic pithoi) on the east, and room L705 (of unknown purpose) on the west (Fig. 1).

A nearly square room L2577, measuring c. 2.40 by $2.30 \mathrm{~m}$, must have been a late addition to the church compound (Fig. 2). The eastern wall of the room (W793) was constructed as to abut on the north-western corner (W245/W792) of the northern annex of the NWC,

\footnotetext{
${ }^{1}$ See: Młynarczyk, Burdajewicz 2013. The correct transliteration of the Aramaic equivalent of the Greek 'Hippos' is 'Susita' rather than 'Sussita'; however, the latter has been commonly accepted in the publications issued by the Zinman Institute, University of Haifa, with whom the Polish team collaborated in the years 1999-2009.

${ }^{2}$ Młynarczyk, Burdajewicz 2007: 64-65, Fig. 91/100-101; 2008: 36-37, Figs 51-54.

${ }^{3}$ On this earthen floor, a golden solidus of Heraclius was found, minted in Constantinople between AD 629 and 631; cf. Berman 2008: 145, no. 40:C 08.01.
} 


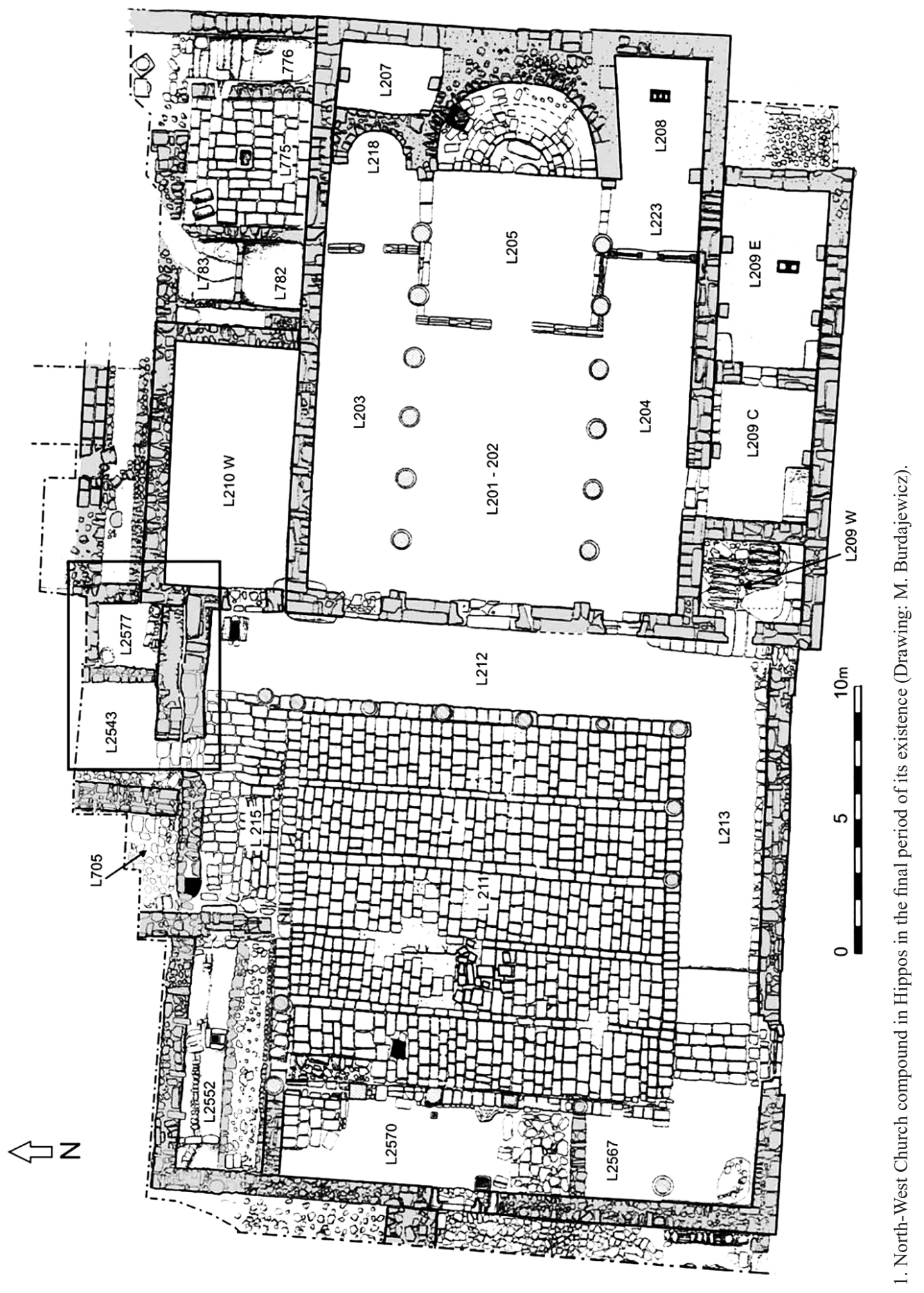




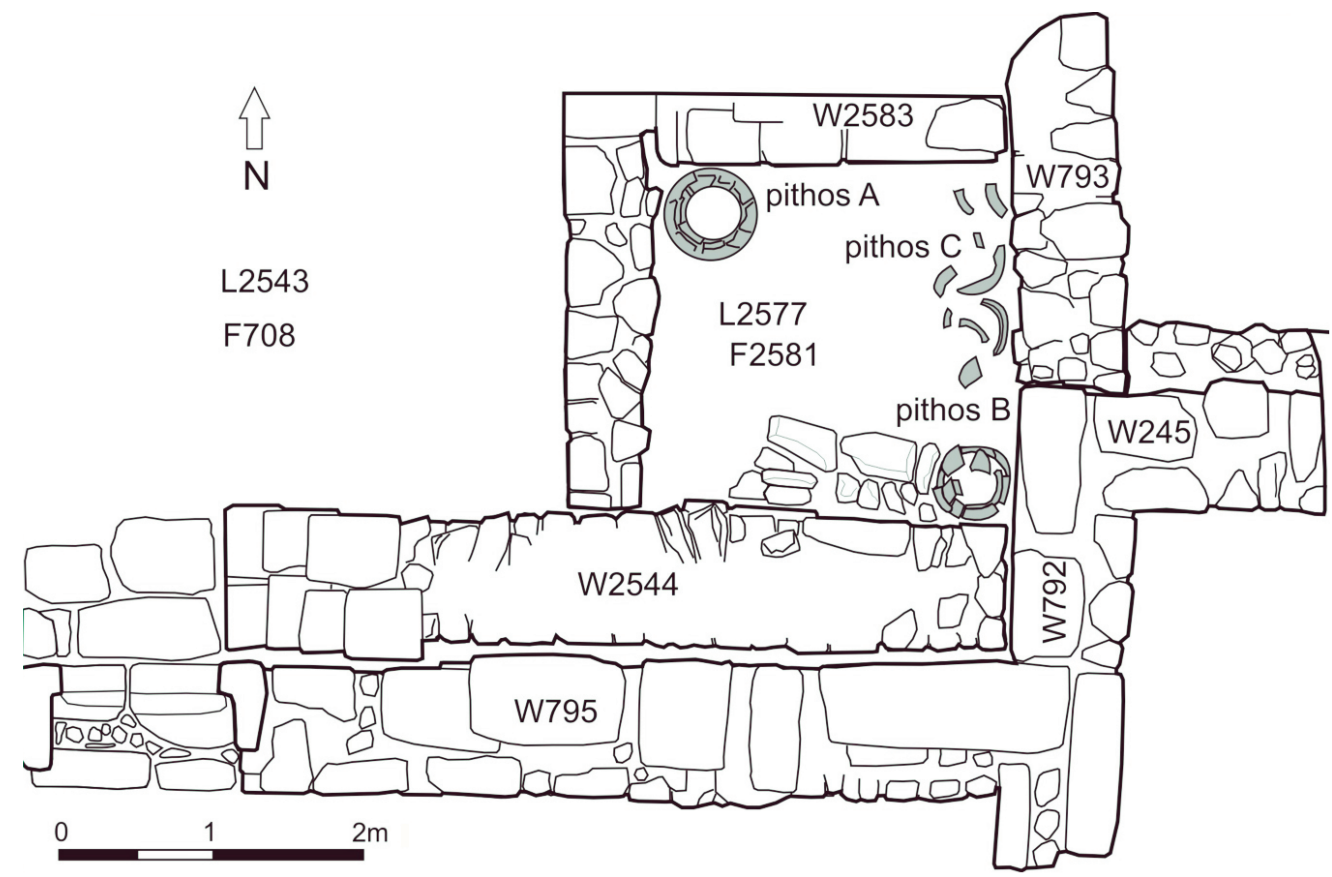

2. Situation of the room with the pithoi (L2577) outside the north-western corner of the church atrium (Drawing: M. Burdajewicz).

while the western wall (W2576) abutted the outer northern wall of the atrium (W2544). The floor of tamped earth mixed with lime mortar and tiny limestones (F2581) was bearing traces of burning. The room apparently served as a storage area equipped with two partially preserved ceramic pithoi in situ: in the north-west (pithos A) and the south-east (pithos B) corner respectively (Fig. 3). With a maximum diameter of 0.60 and $0.50 \mathrm{~m}$, each of them was encased in a frame of stones. In fact, the south-eastern corner pithos B (Fig. 4a) seemed to be placed on a sort of a stone bench, c. $0.25 \mathrm{~m}$ high, constructed along W2544. At this level, large patches of orange-coloured clay were noticed inside the room and initially mistaken for a walking level. Displaced sherds of a third pithos (C) were collected by the eastern wall (W793) of the room.

The contents of the pithoi cannot be ascertained; however, the one standing in the north-west corner of the room (pithos A) had a layer of pure lime on top above what looked like a compact earthen fill (Fig. 4b). The presence of lime lumps in the pithos itself and on the walking level, as well as traces of burning noted on the latter, seem to suggest the proximity of a lime-burning installation, as did the layer of lime found during the season 2001 on the mosaic floor in the western end of the northern aisle of the basilica. ${ }^{4}$ However, the location of the lime kiln itself has never been identified; perhaps it would be found on the northern side of W2583, in the spot which could not be explored for the reasons of

\footnotetext{
${ }^{4}$ Młynarczyk, Burdajewicz 2001: 8 .
} 


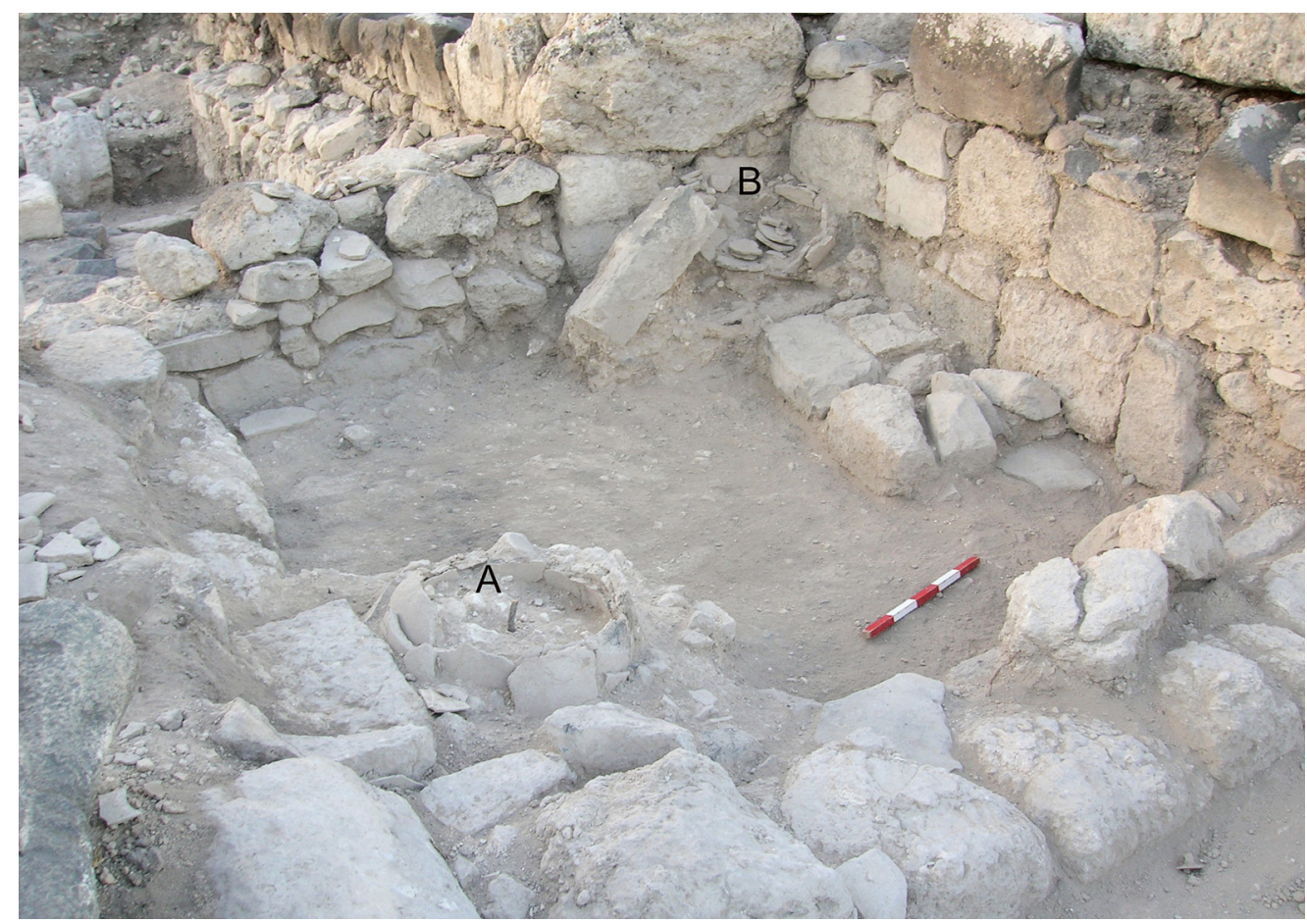

3. Room L2577 with remains of two pithoi in situ, view from the north-west (Phot. J. Młynarczyk).

excavation logistics. The kind of roofing of the pithoi room, if any, could not be determined either. Even if rather many small fragments of roof-tiles were found in the fill, it is not ruled out that it was an open-air room.

During the exploration of the remains of the pithoi it became clear that those preserved in situ (pithos A and B) were placed upside down after their bases had been removed. The installation of the pithoi in the open-air(?) room should doubtlessly be dated to the final period of the church's use, that is, the first half of the eighth century. However, this date is not necessarily the same as the date of their manufacturing, considered that at least two pithoi (A and $\mathrm{B}$ ) must have been in secondary use.

\section{THE TYPOLOGY}

The three discussed pithoi, all of them made by hand, fall into two types, slightly differing in their body profile, but more distinctly in the ware (the fabric plus the exterior surface treatment), both of which are well-attested at Capernaum (see below).

One type is represented by pithos A, which is the main subject of the present paper owing to the acclamation in Greek scratched onto its exterior. ${ }^{5}$ It is made of a light pinkish

\footnotetext{
${ }^{5}$ Jolanta Młynarczyk is responsible for the archaeological and ceramological part of the present article, Adam Łajtar for the epigraphic one.
} 




a

b

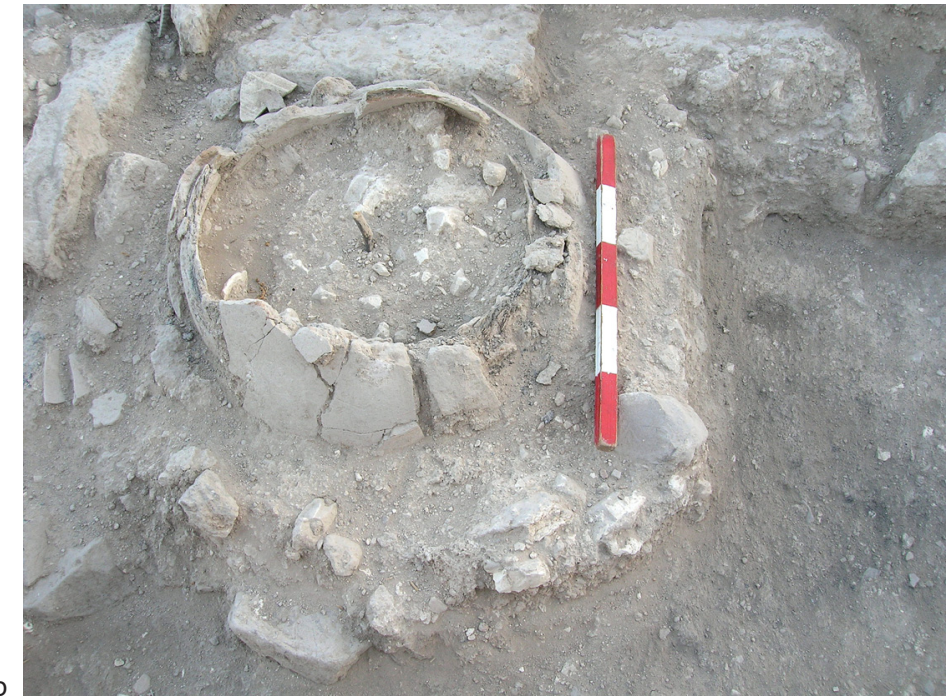

4a. Fragments of pithos B (1277B) in situ in the south-eastern corner of the room; b. remains of pithos A (1277A) in situ in the north-western corner of the same room (Phot. J. Młynarczyk).

brown, 'spongy' (due to numerous voids) fabric, with many pale grey and occasional dark grey grits; the exterior is covered with a smooth red slip. The rim is rounded, just very slightly out-turned and the body gently oval in profile (Fig. 5). The same form and fabric are encountered elsewhere at Hippos, e.g. in a destruction deposit at the so-called HLC area to the east of the Forum. ${ }^{6}$ One of two fragmentary items found there preserves its base, proving that this type of pithos had a tall base ring (a 'footed' base). The same type

${ }^{6}$ Młynarczyk 2009: 109, 122-123, Fig. 4:55, 56a-b. 

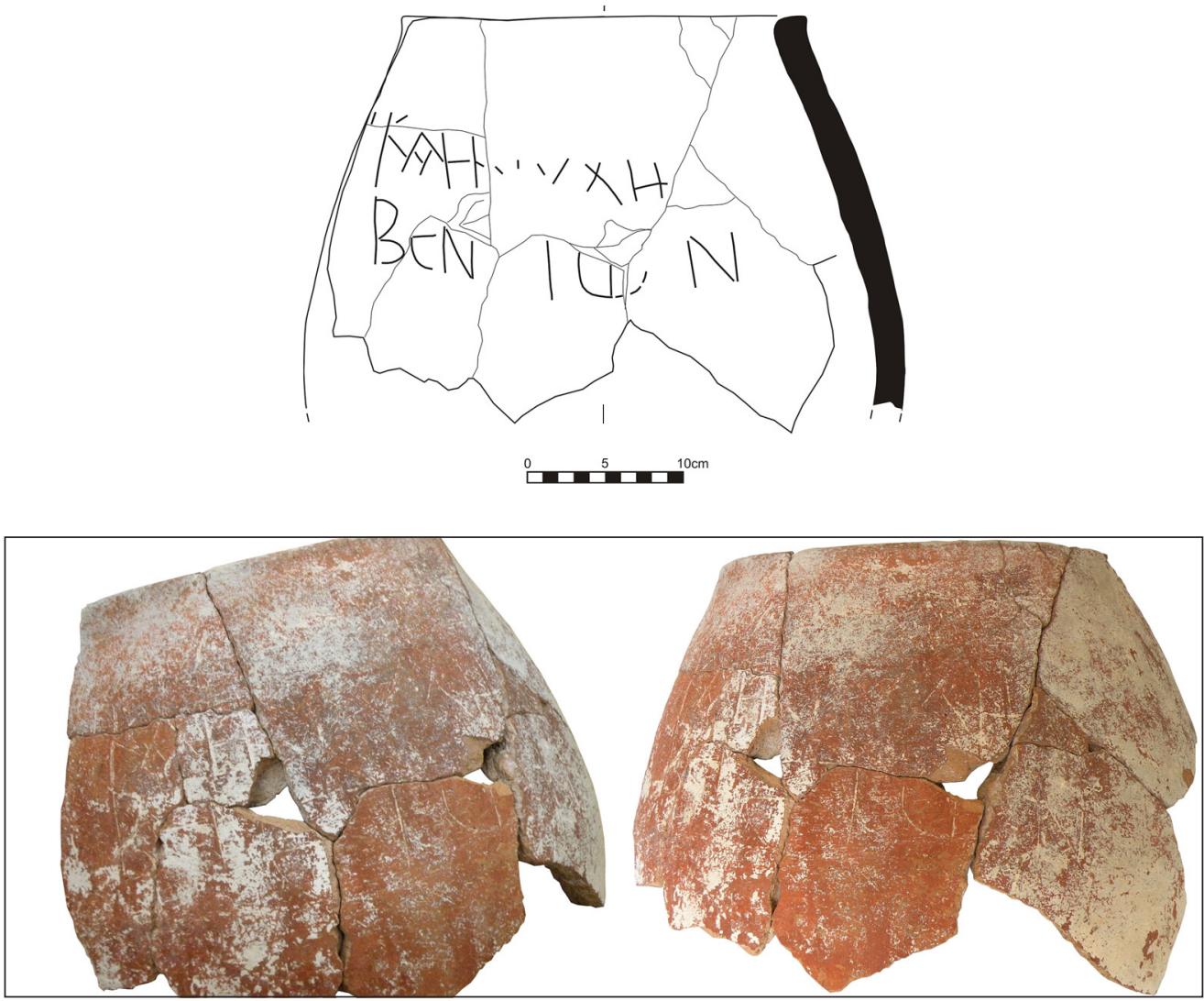

Fig. 5. Restored fragment of pithos A/1277 A with the Blues' faction inscription (Drawing: M. Burdajewicz; Phot. J. Młynarczyk).

(both the form and ware) are present in Capernaum, its examples allegedly coming from contexts dated between $\mathrm{AD} 500$ and $800 .^{7}$

The other type is represented by pithos B and pithos C (Fig. 6a-b). Unlike pithos A, they share a pronouncedly carinated body profile, and represent a different ware. Their fabric is equally 'spongy' (very porous), but fired to light yellowish brown with sizeable white and black grits, while the surface is un-slipped, very porous, fired reddish yellow to light brown. However, these two objects differ from each other in that the wall of pithos $\mathrm{B}$ is plain, while that of pithos $\mathrm{C}$ bears grooved ('combed-style') decoration, at least on its upper half.

Pithos C has many parallels, both at $\operatorname{Hippos}^{8}$ and elsewhere: Capernaum and Khirbet Karak, all of them situated on the Sea of Galilee. In Capernaum, classified as ANF 61, ${ }^{9}$

\footnotetext{
${ }^{7}$ Loffreda 1974: 54-55, Fig. 13:6-7, type D2; 2008a: 150, type ANF 62; 2008b: 109, DG 111.

${ }^{8}$ Młynarczyk 2007: Figs 3:30 and 10:156; 2009: Fig. 11:217.

${ }^{9}$ Loffreda 2008a: 149-150. In Loffreda 1974: 54-55, Fig. 13, and 133, Fig. 47, it was classified as type D1.
} 


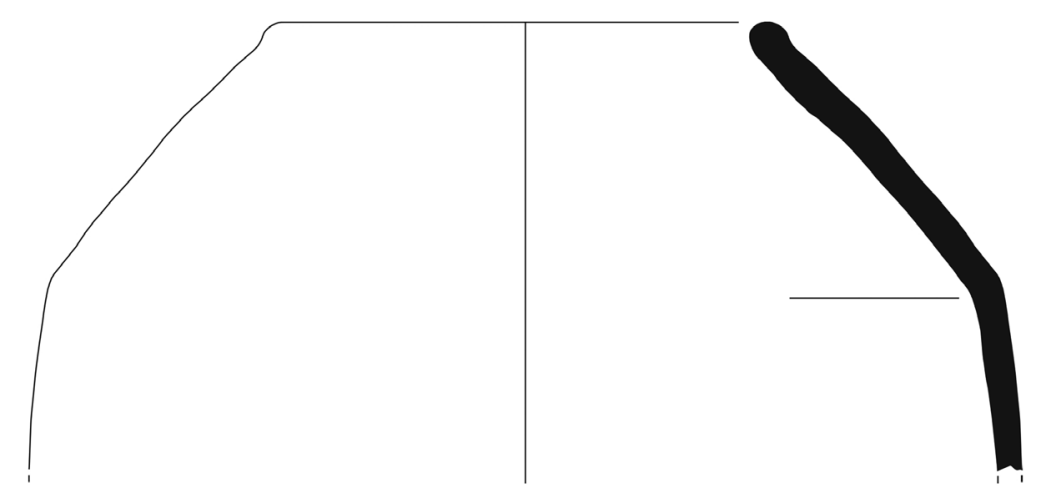

a

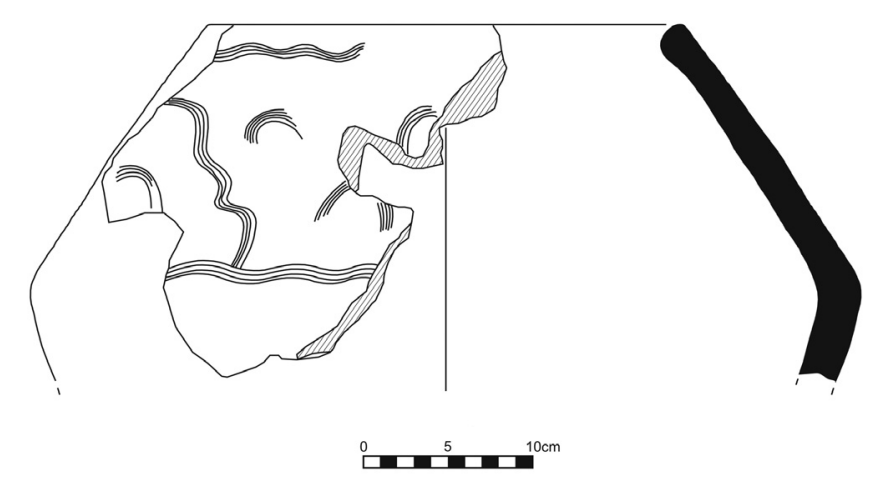

Fig. 6. Fragment of pithos B/1277 B (a) and C/1277 C (b) (Drawing: M. Burdajewicz).

this type was definitely more frequent than the type represented by our pithos A, equal to Capernaum type ANF $62 .{ }^{10}$ However, the attribution of the fragmentary Capernaum examples of ANF 61 to one and the same type may seem disputable, as they include a pithos standing on a flat base alongside two pithoi on tall ring bases. ${ }^{11}$ Actually, as ANF 61, one should consider only those pithoi which stand on tall ring bases, like an example found in Hippos; ${ }^{12}$ in this respect, they parallel Capernaum type ANF 62. Also at Khirbet Karak, a complete jar of this type (grooved decoration, tall ring base) was found. ${ }^{13}$

${ }^{10} 278$ examples of ANF 61 versus just 68 examples of ANF 62; see: Loffreda 2008a: 150, with references to several examples of ANF 61 from other sites in Israel and from Pella in Jordan.

${ }^{11}$ Loffreda 2008b: 108, DG 110, flat based no. 24 versus 'footed' nos 32-33.

${ }^{12}$ Młynarczyk 2009: Fig. 4:57.

${ }^{13}$ Cf. Delougaz, Haines 1960: P1. 38:12 = P1. 58:8; for other possible parallels, namely from Bet Shean, Pella, Yoqne'am and perhaps Sepphoris, see: Loffreda 2008a: 149-150. 


\section{THE CHRONOLOGY}

The traditional utilitarian storage vessel such as pithos is extremely difficult to date because, unlike the other kinds of pottery vessels, its shape was changing very slowly with time. It is obvious that the large, hand-made pithoi from Hippos (as in other centres) were manufactured on site, while the raw material (the clay) may theoretically have been brought from another locality. In terms of archaeological contexts, Capernaum type ANF 61 (corresponding to our pithos $\mathrm{C}$, and as regards the shape and the ware also to pithos $\mathrm{B}$ ) is defined as 'forma tipicamente bizantina (350-650 dC)'. ${ }^{14}$ Also in Bet Shean, it is said to have occurred in a late Byzantine-period stratum. ${ }^{15}$ However, in some cases the type's dating is extended to the early Islamic period, e.g. in eastern Capernaum, where a rim fragment was attributed to a stratum of $\mathrm{AD} 650-750^{16}$ or Khirbet Karak. ${ }^{17}$ Among the Hippos finds of this type, a rim fragment comes from a context containing ceramics of late Roman and Byzantine periods, mid-fifth to early seventh century. ${ }^{18}$

As to apparently less common pithos type Capernaum ANF 62 (corresponding to our inscribed pithos A), there is less dating evidence. Actually, it comes only from Capernaum, where fragments of the type were recovered from contexts described as Byzantine, late Byzantine and 'periodo arabo' with some residual Byzantine material. ${ }^{19}$ It seems reasonable to ascribe this type of pithos with red external slip to not later than the Byzantine (and before early Islamic) period. The faction inscription of our pithos A, apparently ante-dating the Islamic conquest of $\mathrm{AD}$ 636/638, is in favour of such dating. It is after a century or so from the time of its manufacturing that the pithos was placed upside down in a subsidiary room outside the atrium of the North-West Church to be re-used for the storage of the lime(?).

Pithos A carries an incised inscription in Greek on its external side, in the upper part of its body, not far from the rim. The inscription must have been executed during the use of the pithos as suggested by the technique of execution and the position of the writing. The text is $c .24 \mathrm{~cm}$ wide and $c .9 \mathrm{~cm}$ high, with letters ranging in height between 3.5 and $4 \mathrm{~cm}$. The letters are carved lightly and freely. Palaeographically they resemble upright epigraphic majuscules; note especially alpha in line 1 which is of the type 'alpha à barre brisée', characteristic of the monumental script. The hand is definitely well trained although not very careful while writing on that occasion, which is especially evident in line 2 where the letters are first tightly arranged and then widely spaced, and they do not form a straight

\footnotetext{
${ }^{14}$ Loffreda 2008a: 149; 1974: 54-55 and 133, Type D1 (late Roman-to-Byzantine).

${ }^{15}$ Avshalom-Gorni 2004: 102, Fig. 10:1-3.

${ }^{16}$ Peleg 1989: 92-93, Fig. 61:6.

${ }^{17}$ Delougaz, Haines 1960: 37.

${ }^{18}$ Młynarczyk 2007: 113, no. 156.

${ }^{19}$ Loffreda 2008a: 150.
} 
line. A note should be taken that iota at the beginning of line 1 is marked as a short vertical stroke at the top of line height. Perhaps this is not iota at all and the first syllable of the word $v \imath \kappa \hat{\alpha}$ was inscribed much to the left, in the part of the pithos that is now lost. This

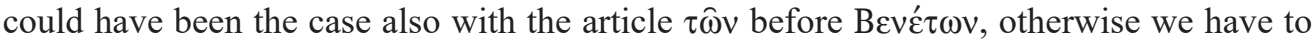
assume that the article was omitted (as in the text printed below).

The inscription can be transcribed as follows:

$[v]$ $\kappa \hat{\alpha} \dot{\eta} \tau u ́ \chi \eta$

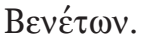

\section{The fortune of the Blues triumphs.}

2. The article $\tau \hat{\omega} v$ is omitted before the name of a faction in some further factions' acclamations (however, see description of the inscription above).

What we have before us is a faction acclamation constructed according to the well-known pattern: vıkộ $\dot{\eta} \tau \hat{\chi} \chi \eta+$ the name of a faction in genitive plural. Acclamations of this type are attested by inscriptions coming from throughout the Byzantine world ${ }^{20}$ including such places as Constantinople, ${ }^{21}$ Ephesos, ${ }^{22}$ Didyma, ${ }^{23}$ Stratonikeia in Caria, ${ }^{24}$ Aphrodisias, ${ }^{25}$ Phoenicia, ${ }^{26}$

\footnotetext{
${ }^{20}$ For a collection of factions' inscriptions see: Cameron 1976: 314-317. Note, however, that his list includes not only acclamations of the type vıкộ $\dot{\eta} \tau \hat{v} \chi \eta$ + the name of a faction, but also other inscriptions mentioning Blues and Greens. On inscriptions mentioning factions see also: Roueché 2007a: 62-64.

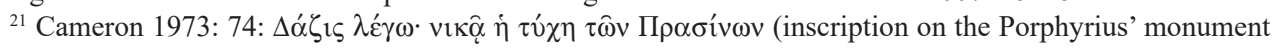
raised up in the hippodrome in Constantinople). Another circus acclamation from Constantinople is CIG IV

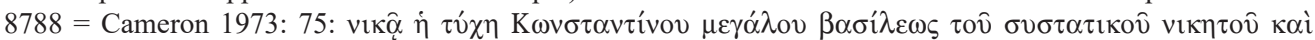

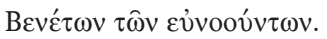

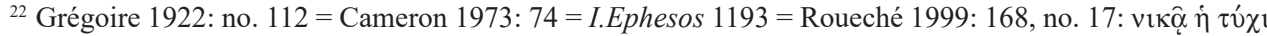

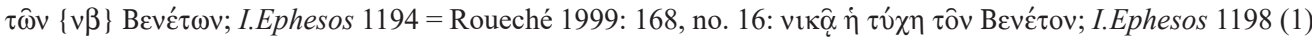

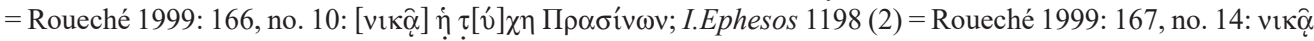

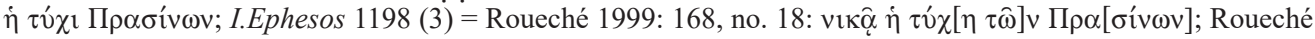


Fig. 2. Generally on factions' acclamations in Ephesos, see: Roueché 1999.

${ }^{23}$ Grégoire 1922: no. 226 ter = I.Didyma 609 = Cameron 1973: 74: vıкộ $\dot{\eta} \tau$

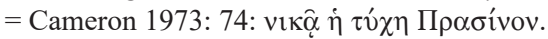

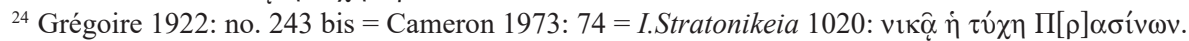



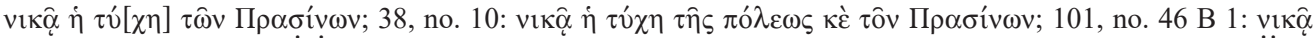



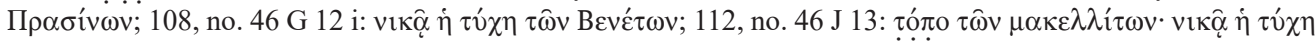

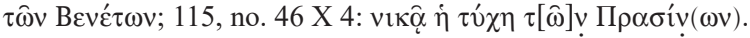

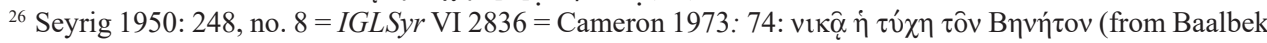

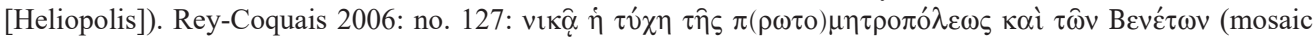
inscription in the hippodrome of Tyre; note that the reading $\pi(\rho \omega \tau 0) \mu \eta \tau \rho \circ \pi$ ó $\lambda \varepsilon \omega \varsigma$ is not certain; it can also be

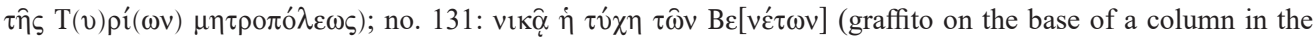
hippodrome of Tyre). The two latter inscriptions are also available as SEG LII 1601 and 1605 respectively.
} 
south Syria, ${ }^{27}$ Arabia, ${ }^{28}$ Palestine,${ }^{29}$ Alexandria ad Aegyptum, ${ }^{30}$ Antinoe in Middle Egypt,${ }^{31}$ Thessaly, ${ }^{32}$ and Crete. ${ }^{33}$ Inscriptions with the vıkố $\dot{\eta} \tau \hat{\chi} \chi \eta$ acclamation are generally dated to the sixth-seventh century AD. The oldest known item seems to be the acclamation inscribed on the Porphyrius' monument that was set up in the hippodrome in Constantinople $c$. AD $500,{ }^{34}$ the youngest - the acclamation of the Emperor Constantine (perhaps Constantine $\mathrm{V}$ [better IV], AD 668-685) and the Blues, also from Constantinople. ${ }^{35}$ This nearly twocenturies period of occurrence of the $v \imath \kappa \hat{\alpha} \dot{\eta} \tau \dot{v} \chi \eta$ acclamations corresponds with the period of the highest rioting activity of the factions after the fusion of the circus and the theatre fan clubs towards the end of the fifth century $\mathrm{AD}^{36}$ and the more formal involvement of Blues and Greens, within the seventh century $\mathrm{AD}$, into the court and church ceremonial

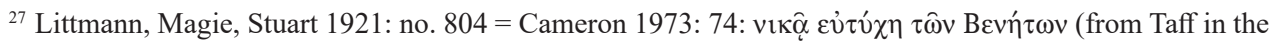
Ledja).

${ }^{28}$ Littmann, Magie, Stuart 1921: 148-149, nos 256 and $266=$ Cameron 1973: $74=$ IGLSyr XXI 5147 and


from the Syrian border). Another inscription from the same site may preserve an acclamation of the Red; cf. $L B W$, no. $2425=$ Littmann, Magie, Stuart 1921: $148=$ Cameron 1976: 72 and 316. The text reads: vıкô

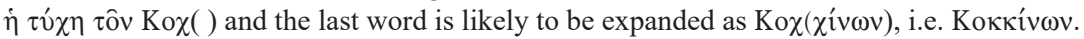

${ }^{29}$ Syon 2004: 14 with Fig. 17 (SEG LIV 1678; read by R. Tybut on the photograph): vıкố $\dot{\eta} \tau \dot{\chi} \chi \eta \tau \hat{\eta} v$ Bevé $\tau \omega v$ (inscription of a mosaic set in the sidewalk at the entrance to one of the shops in Bet Shean; note that the dating of the inscription to the fourth/fifth century suggested in SEG on the basis of archaeological criteria is too early by at least one hundred years). vıкQ̣̂ $\dot{\eta} \tau \hat{v} \chi \eta$ formula ought not to be restored in an inscription from Jerusalem mentioning the Blues (SEG VIII 213; Cameron 1976: 316; CIIP I 2, 1026).

${ }^{30}$ A collection of factions acclamation was found inscribed on the seats of the theatre-like building found by the Polish archaeologists on Kom el-Dikka. They were published in Borkowski 1981. Those with the formula:

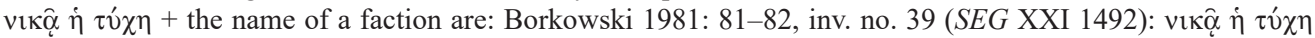

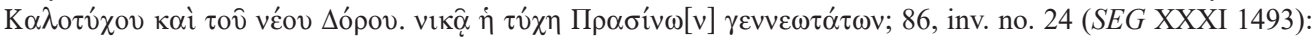

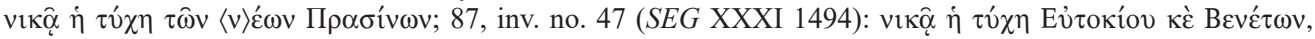

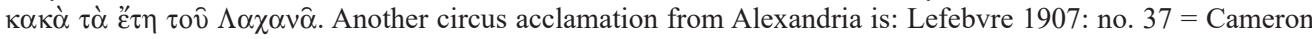
1973: 75: vıк人ิ

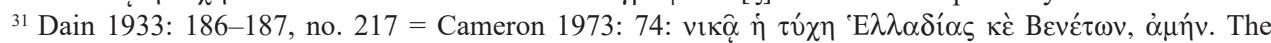
inscription stands on two sides of a comb. Helladia could have been a dancing-girl. For this object, see more recently Rutschowscaya 2000.

${ }^{32}$ Lazaridis 1969: 21 with P1. 23a = Cameron 1973: 276 = Cameron 1976: 149 and 314; republished in

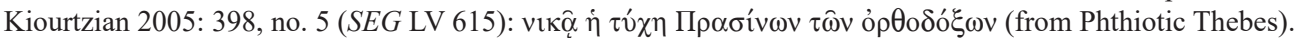

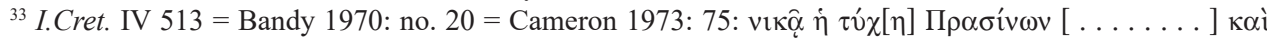

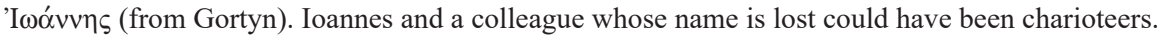

${ }^{34}$ Equally old is the acclamation to the metropolis and the Blues in a mosaic in the hippodrome of Tyre, dated to $\mathrm{AD} 502$; for reference, see above, n. 26.

${ }^{35}$ For reference, see above, n. 21. The identity of the emperor in question is a matter of controversy. For a recent discussion see: Missiou 1985.

${ }^{36}$ See Cameron 1976: especially 193-229, chap. VIII. Cameron (1976: 193), calls attention to five facts that are important in connection with the inscription here discussed. 1) In the early Empire, up to and including the fourth century, the factions (partisans and professionals alike) were solely concerned with the circus - that is to say with chariot-racing. By the late fifth century we find that both partisans and professionals of the theatre and amphitheater too are regularly called by the name of the four circus colours. 2) From the late fifth century on virtually every demonstration or riot in circus, theatre or amphitheater is expressly or implicitly ascribed to the two major colours: Blues and Greens. Before that date not one such disturbance is ascribed to circus partisans. 3) It is from this same date again, the late fifth century, that we first begin to hear of regular and violent confrontations between Blues and Greens throughout the eastern cities. 4) Before (once more) probably the late fifth century, Blues and Greens simply did not exist in the eastern cities, except for Alexandria and Constantinople.
} 
that tempered their rowdyism. ${ }^{37}$ Our inscription from Hippos should undoubtedly be placed within this chronological framework, however a more exact date is difficult to establish due to the lack of safe dating criteria. One can only suppose that it is older than the Arab invasion of Syria and Palestine in AD 637, which must have impeded the functioning of Byzantine social institutions in this area. ${ }^{38}$ It should be noted that this date refers only to the fact of inscribing the acclamation on the pithos. The secondary use of the pithos in a room adjacent to the North-West Church could have occurred much later, in the second half of the seventh or the first half of the eight century AD.

Among the factions' inscriptions featuring the vıkộ $\dot{\eta} \tau u ́ \chi \eta$ acclamation two well-defined groups can be distinguished. The first group, best represented by the finds from Ephesos, Didyma and Aphrodisias, contains well cut texts placed in public spaces, often in connection with acclamations of state and civic institutions. These should be considered as formal and official inscriptions testifying to the involvement of the Blues and the Greens in public ceremonial, as Charlotte Roueché has demonstrated recently. ${ }^{39}$ The second group, of which the best representatives are the inscriptions on the seats of the theatre-like building on Kom el-Dikka in Alexandria, ${ }^{40}$ consists of casual graffiti left most probably by the partisans. Our inscription undoubtedly belongs to this second group. It must have been executed by someone who had direct access to the pithos and was eager to express his factional sympathies.

It is difficult, and even dangerous, to draw conclusions of a general nature from this modest text. As is well known, circus and theatre spectacles played a prominent role in social life during the period of late Antiquity. Circuses existed in all major cities of the then empire, ${ }^{41}$ while theatres must have been still more common as they require less space than circuses. Theatrical spectacles could have been organized with lesser expenditures than chariot races since a troupe of travelling actors could have performed almost everywhere, even on an open square. The professional performers along with a certain number of the most devoted among the fans, commonly referred to as 'young men' in contemporaneous sources, were organized in clubs called factions by modern scholars. ${ }^{42}$ Of the four existing factions named after the colours of the jackets worn by the charioteers - Greens, Blues, Reds,

5) Circus partisans should not be recorded in the eastern cities before then, because (contrary to popular opinion) chariot-racing itself (in Roman style) was virtually unknown in the East.

${ }^{37}$ Cf. Cameron 1976: 297-308, chap. XI.

${ }^{38}$ The question is a matter of discussion, however. Some scholars suggested that the Byzantine factions survived the Arab invasion and influenced the Islamic futuwwa organizations; cf. Vryonis Jr. 1965: 46-59 with rather sceptical remarks by Cameron 1976: 341-343, Appendix G.

${ }^{39}$ Roueché 1984; 1983: 143-156.

${ }^{40}$ In earlier works by Polish scholars involved in the publication of the results of Kom el-Dikka excavations, this theatre-like building was identified as a gathering place for members of the Green faction (so in Borkowski 1981). Recently it was brought into connection with some 20 auditoria discovered in the neighbourhood and considered as the main lecture hall of the Alexandrian university; cf. Derda, Markiewicz, Wipszycka (Eds) 2007.

${ }^{41}$ Humphrey 1986. For the period in question (sixth-seventh century AD), the circuses are attested in Beirut, Tyre, Caesarea, Bostra, Gerasa, and perhaps also Gadara; cf. Humphrey 1986: 438-539, especially 461-505. For the circus in Gerasa, see especially: Ostrasz 1989.

${ }^{42}$ We use the term 'faction' here and throughout the article although we are well aware of its conventional and not technical character. For the factions the most seminal study still remains Cameron 1976. 
and Whites - the two former played a dominant role. The sources constantly present them as fervent rivals to one another, and their rivalry undoubtedly evoked an echo in society, although Procopius is probably exaggerating when he writes in a much-quoted passage, that the whole population of the Empire was divided into the Blues and the Greens. ${ }^{43}$

When seen in this light, the inscription under scrutiny hardly testifies to more than the presence of the partisans of the Blues, perhaps organized in a faction, in Hippos in the sixth/seventh century AD. ${ }^{44}$ It is even not proof that the city possessed a circus in which chariot races in Roman style were organized, ${ }^{45}$ although the existence of a circus within the area of Hippos was suggested on the basis of other premises. ${ }^{46}$ The partisans of the Blues in Hippos could have found nourishing substance in chariot races in one of the neighbouring cities with circuses or in the theatre activity. ${ }^{47}$ Our inscription can in no way be considered as proof of the social or religious tensions of the period. Such considerations, common in scholarship from the late nineteenth and the first half of the twentieth century $\mathrm{AD}$, are completely unfounded, as Alan Cameron demonstrated in his seminal study on the circus factions. ${ }^{48}$ Neither can the inscription be connected with the Jews, who are known to have had sympathy for the Blues ${ }^{49}$ and surely inhabited Hippos in the Byzantine period. To exclude such a possibility it suffices to say that the object was found in an immediate vicinity of a church and even if it was used there in a secondary context it was surely not brought from a Jewish entourage.

A strange phenomenon can be observed while looking at the vıкộ $\dot{\eta} \tau \hat{\chi} \chi \eta$ acclamations from the Syro-Palestinian area, including the acclamation discussed herein. With the exception of one unclear item from Umm el-Jimal in Arabia, which may be for the Reds, all of them are for the Blues. This is undoubtedly a matter of pure coincidence. There must have been the Greens where there were the Blues and the partisans of both factions surely had the same behaviours in the matter of leaving written acclamations, but strangely only the acclamations of the latter faction have survived to the present day.

\section{Acknowledgments}

The exploration project of the North-West Church Compound (NWC) in Hippos-Sussita was supported by two grants, one of them (1H01 B009 29 of the Ministry of Science and Higher Education) destined to carry out the study of liturgical functioning of the church in question, while the other (2012/07/B/HS3/02378 of the National Science Centre) aided us in preparing the future monograph of the church.

\footnotetext{
${ }^{43}$ Procopius, De Bello Persico I 24, 2; Anecdota VII 1.

${ }^{44}$ For the presence of the Blues and the Greens in Byzantine Palestine see: Dan 1981 (non vidimus).

${ }^{45} \mathrm{Cf}$. a remark by Cameron 1976: 196: It must be recognized that from the fifth century on a reference to Blues and Greens in a city need not imply that the city in question had a hippodrome.

${ }^{46}$ According to Arthur Segal, an elongated depression in the valley neighbouring the Hippos acropolis from the east may be a remnant of a hippodrome. The hypothesis needs field research to be proven positively.

${ }^{47}$ For the world of public spectacles in Roman and late Antique Palestine, see: Weiss 2014.

${ }^{48}$ Cameron 1976: 126-153.

${ }^{49}$ Van der Horst 2003; reprinted in: 2006: 53-58.
} 


\section{References}

Avshalom-Gorni, D. 2004: Remains from the Byzantine to Ottoman Periods at Bet She'an: Salvage Excavations West of the Amphitheater, 'Atiqot 46, 134*-135*, 93-111

Bandy, A.C. 1970: The Greek Christian Inscriptions of Crete, Athens

Berman, A. 2008: Hippos - Sussita $9^{\text {th }}$ Season (2008). Coins Catalogue, [in:] Segal, A. et al., Hippos - Sussita. Ninth Season of Excavations (June-July 2008), Haifa, 143-162

Borkowski, Z. 1981: Inscriptions des factions à Alexandrie, Alexandrie II, Varsovie Cameron, A. 1973: Porphyrius the Charioteer, Oxford

Cameron, A. 1976: Circus Factions. Blues and Greens at Rome and Byzantium, Oxford Dain, A. 1933: Inscriptions grecques du Musée du Louvre, Les textes inédits, Paris

Dan, Y. 1981: Circus Factions (Blues and Greens) in Byzantine Palestine, [in:] Levine, L.I. (Ed.), The Jerusalem Cathedra: Studies in the History, Archaeology, Geography and Ethnology of the Land of Israel I, Jerusalem, 105-119

Delougaz, P., Haines, R.C. 1960: A Byzantine Church at Khirbat al-Karak, OIP 85, Chicago

Derda, T., Markiewicz, T., Wipszycka, E. (Eds) 2007: Alexandria. Auditoria of Kom el-Dikka and Late Antique Education, JJP-Suppl. VIII, Warsaw

Grégoire, H. 1922: Recueil des inscriptions grecques-chrétiennes d'Asie mineure, Paris Humphrey, J.H. 1986: Roman Circuses. Arenas for Chariot Racing, Berkeley-Los Angeles Kiourtzian, G. 2005: Enépigraphos plinthos, [in:] Baratte, F. et al. (Eds), Mélanges Jean-Pierre Sodini, Travaux et Mémoires 15, Paris, 381-398

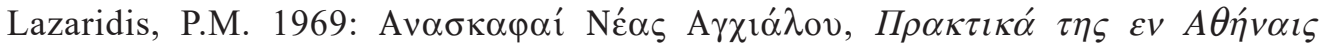

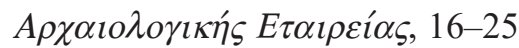

Lefebvre, G. 1907: Recueil des inscriptions grecques-chrétiennes d'Égypte, Le Caire

Littmann, E., Magie, D., Stuart, D.R. 1921: Publications of the Princeton University Archaeological Expedition to Syria III: Greek and Latin Inscriptions. Southern Syria, Leiden

Loffreda, S. 1974: La ceramica, Cafarnao II, Jerusalem

Loffreda, S. 2008a: Tipologie e contesti stratigrafici della ceramica (1968-2003), Cafarnao VI, Jerusalem

Loffreda, S. 2008b: Documentazione grafica della ceramica (1968-2003), Cafarnao VII, Jerusalem

Missiou, D. 1985: Who was the Constantine in the inscription no. 8788 CIG IV? A contribution to the study of the demes in the period of the Herakleids, Byzantina 13/II, 1477-1486

Młynarczyk, J. 2007: Pottery Report, [in:] Segal, A. et al., Hippos - Sussita. Eighth Season of Excavations (July 2007), Haifa, 105-154

Młynarczyk, J. 2009: Pottery Report, [in:] Segal, A. et al., Hippos - Sussita. Tenth Season of Excavations (July and September 2009), Haifa, 104-156

Młynarczyk, J., Burdajewicz, M. 2001: North-West Church Complex, [in:] Segal, A., Młynarczyk, J., Burdajewicz, M., Hippos (Sussita). Second Season of Excavations, July 2001, Haifa, 7-13 
Młynarczyk, J., Burdajewicz, M. 2007: North-West Church Complex (NWC), [in:] Segal, A. et al., Hippos - Sussita. Eighth Season of Excavations (July 2007), Haifa, 61-71

Młynarczyk, J., Burdajewicz, M. 2008: North-West Church Complex (NWC), [in:] Segal, A. et al., Hippos - Sussita. Ninth Season of Excavations (June-July 2008), Haifa, 36-39

Młynarczyk, J., Burdajewicz, M. 2013: The Northwest Church Complex, [in:] Segal, A. et al., Hippos - Sussita of the Decapolis. The First Twelve Seasons of Excavations 2000-2011, I, Haifa, 194-221

Ostrasz, A. 1989: The hippodrome of Gerasa: A report on excavations and research 1982-1987, Syria LXVI, 51-77

Peleg, M. 1989: Domestic pottery, [in:] Tzaferis, V., Excavations at Capernaum I: 1978-1982, Winona Lake, 31-113

Rey-Coquais, J.-P. 2006: Inscriptions grecques et latines de Tyr, Baal. Bulletin d'archéologie et d'architecture libanaises, Hors-série III, Beyrouth

Roueché, Ch. 1984: Acclamations in the Later Roman Empire: New Evidence from Aphrodisias, JRS 74, 181-199

Roueché, Ch. 1993: Performers and Partisans at Aphrodisias in the Roman and Late Roman Periods, JRS Monograph 6, London

Roueché, Ch. 1999: Looking for Late Antique Ceremonial: Ephesos and Aphrodisias, [in:] Friesinger, H., Krinzinger, F. (Eds), 100 Jahre österreichischen Forschungen in Ephesos. Akten des Symposions Wien 1995, DÖAWW, Philosophisch-historische Klasse 260, Vienna, 161-168

Roueché, Ch. 2007a: Spectacles in Late Antiquity: some observations, AntTard 17, 59-64

Roueché, Ch. 2007b: Interpreting the Signs: Anonymity and Concealment in Late Antique inscriptions, [in:] Amirav, H., ter Haar Romeny, B. (Eds), From Rome to Constantinople. Studies in Honour of Averil Cameron, Leuven-Paris-Dudley, Mass., 221-234

Rutschowscaya, M.-H. 2000: Le peigne d'Helladia, [in:] Bosson, N. (Ed.), Neuvième journée d'études, Montpellier, 3-4 juin 1999, Études Coptes 7, Cahier de la Bibliothèque copte 12, Paris, 235-244

Seyrig, H. 1950: Antiquités syriennes, Syria XXVII/3-4, 229-252

Syon, D. 2004: Bet She'an, HadArkh 116, 12*-16*

Van der Horst, P.W. 2003: Jews and Blues in Late Antiquity, [in:] Accorinti, D., Chuvin, P. (Eds), Des Géants à Dionysos. Mélanges de mythologie et de poésie grecques offerts à Francin Vian, Alexandria, 565-572

Van der Horst, P.W. 2006: Jews and Christians in Their Graeco-Roman Context. Selected Essays on Early Judaism, Samaritanism, Hellenism, and Christianity, WUNT 196, Tübingen

Vryonis, Sp., Jr. 1965: Byzantine circus factions and Islamic Futuwwa organizations, ByzZeit 58, 46-59

Weiss, Z. 2014: Public Spectacles in Roman and Late Antique Palestine, Revealing Antiquity 21, Cambridge, Mass.-London 


\section{ÉTUDES et TRAVAUX XXX / 2017}

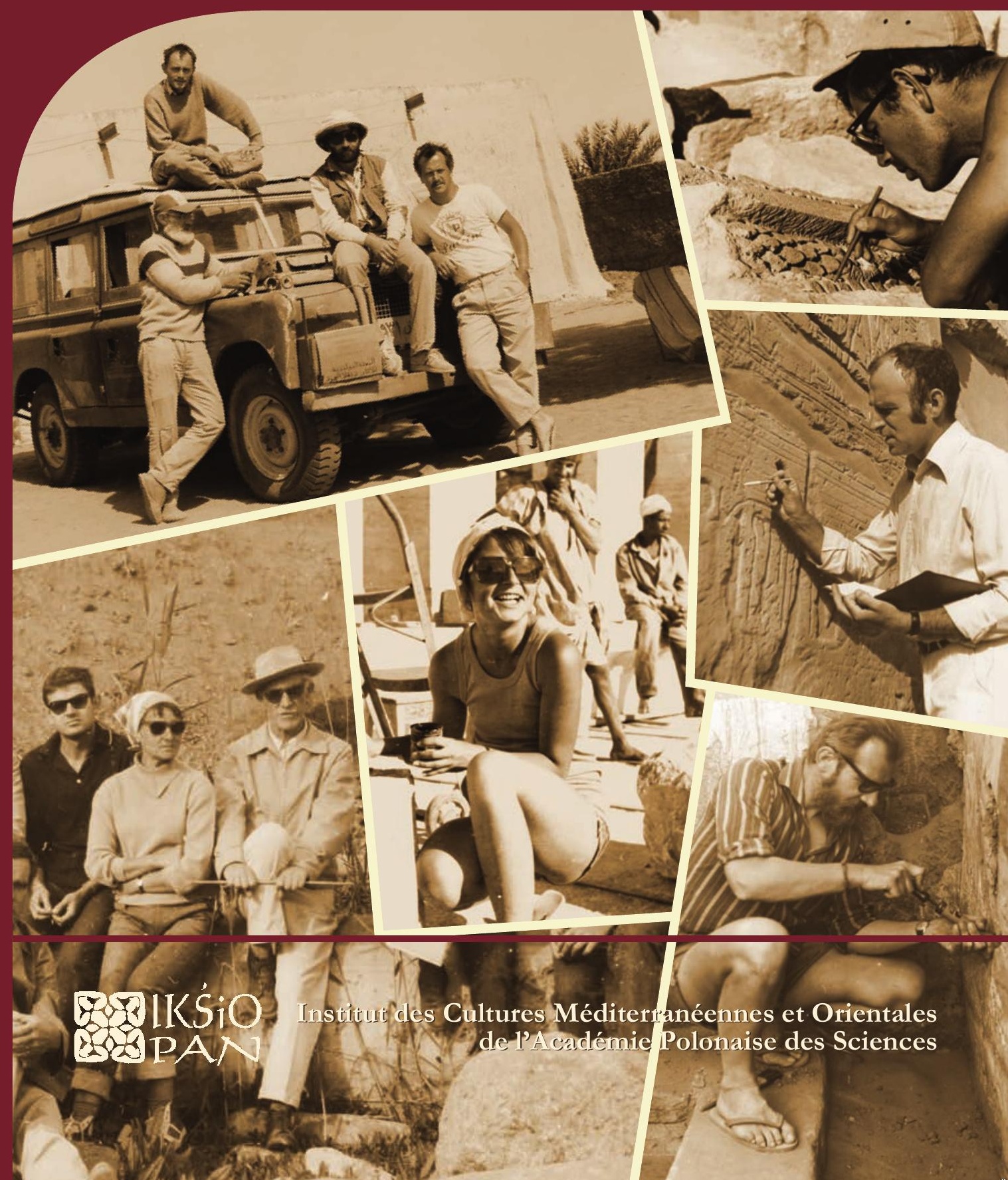




\title{
COMITÉ DE RÉDACTION SCIENTIFIQUE
}

Maciej Makowski - rédacteur en chef

Jadwiga Iwaszczuk - rédacteur et sécretaire de la rédaction

Mariusz Drzewiecki - rédacteur

Maciej G. Witkowski - rédacteur

\section{CONSEIL SCIENTIFIQUE DU JOURNAL}

M. Kobusiewicz (IAE PAS, Warszawa), E. Laskowska-Kusztal (IMOC PAS, Warszawa),

D. Michaelides (University of Cyprus, Nicosia),

J.Ch. Moretti (IRAA-MOM, Université de Lyon 2/CNRS),

D. Raue (Ägyptisches Museum der Universität Leipzig), P. Reynolds (ICREA, Barcelona),

D. Welsby (British Museum, London)

\section{COMITÉ SCIENTIFIQUE DE LECTURE}

J. Holaubek (Institut für Ägyptologie, Wien), S. Ikram (AUC, Cairo),

K. Innemée (Universiteit Leiden), J. McKenzie (Faculty of Oriental Studies, University of Oxford),

N. Strudwick (University of Cambridge), A. Loprieno-Gnirs (Universität Basel),

Ch.E. Loeben (Museen für Kulturgeschichte, Hannover), Y. Tristant (Macquarie University, Sydney),

V.W.J. van Gerven Oei (University of Aberdeen), A. Peignard-Giros (HiSoMA-MOM, Université de Lyon 2/CNRS), J.A. Ostrowski, E. Papuci-Władyka, J. Śliwa (IA JU, Kraków), R. Czerner (WUST, Wrocław), A. Ćwiek (IA AMU, Poznań), M. Wiewióra (IA NCU, Toruń), K. Domżalski

(IAE PAS, Warszawa), K.O. Kuraszkiewicz (DE FOS UW), M. Barwik, P. Bieliński, P. Dyczek, W. Godlewski, D. Ławecka, S. Rzepka, J. Żelazowski, M. Gawlikowski, J. Młynarczyk, A. Niwiński, T. Sarnowski, D. Szeląg, T. Waliszewski (IA UW, Warszawa)

\section{RÉDACTEUR THÉMATIQUE DU VOLUME \\ Barbara Lichocka}

\author{
AIDE RÉDACTION TECHNIQUE \\ Dorota Dobrzyńska, Mariusz Drzewiecki
}

REVUE DES TEXTES ANGLAIS

Jo Harper 
ÉTUDES et TRAVAUX XXX 
INSTYTUT KULTUR ŚRÓDZIEMNOMORSKICH I ORIENTALNYCH POLSKIEJ AKADEMII NAUK

\section{STUDIA i PRACE}

XXX

\section{Ro IKŚSiO \\ ESA PAN}

WARSZAWA

2017 
INSTITUT DES CULTURES MÉDITERRANÉENNES ET ORIENTALES DE L'ACADÉMIE POLONAISE DES SCIENCES

\section{ÉTUDES et TRAVAUX}

XXX

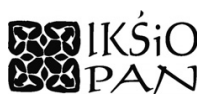

VARSOVIE

2017 
Publication scientifique financée dans le cadre du programme du Ministre de la Science et de l'Éducation Supérieure

« Programme National de Développement de l’Humanistique » pour les années 2016-2021 (projet no 3bH 150099 83)

\title{
HARODOWY PROGRAM ROZWOJU HUMANISTYKI
}

\author{
Copyright (C) \\ Instytut Kultur Śródziemnomorskich i Orientalnych PAN \\ et les Auteurs \\ Warszawa 2017
}

\author{
ISSN 2084-6762 \\ (avant $2011: 0079-3566$ ) \\ e-ISSN 2449-9579 \\ Version première en papier, imprimée en Pologne - 150 copies \\ Version électronique accessible sur \\ http://www.etudesettravaux.iksiopan.pl
}

Édition: Polskie Towarzystwo Historyczne et Wydawnictwo Neriton, Warszawa

Conception générale de couverture : J. Iwaszczuk

Photos de couverture : En haut, à gauche. Vieille Dongola 1991, S. Jakobielski

(debout à gauche), K. Pluskota (debout à droite), B. Żurawski (assis sur le camion)

et P. Wierzbicki (assis sur le camion) (de la collection de B. Żurawski)

En haut, à droite. Palmyre 1964, M. Marciniak au travail (phot. A. Dziewanowski)

Au centre. E. Laskowska-Kusztal au travail (de la collection de E. Laskowska-Kusztal)

En bas, à gauche. Tell Atrib 1962 ; de gauche : T. Biniewski, M. Marciniak, K. Kołodziejczyk,

K. Michałowski, A. Ostrasz, S. Jakobielski et S. Jasiewicz devant eux

(de la collection de IKŚSiO PAN).

En bas, à droite. Vieille Dongola 1976, S. Jakobielski nettoyant le mur (phot. M. Steinborn).

Au centre, à droite, K. Myśliwiec en train des travaux de documentation (de la collection de IKŚiO PAN) 


\section{Table des matières}

BARBARA LICHOCKA

Ergon agathon

Hartwig Altenmüller

$\mathrm{Zu}$ den Feindbildern auf den Zauberstäben des Mittleren Reiches und der Zweiten

Zwischenzeit

Nathalie Beaux

Des $m s w n s w$ de Thoutmosis III à Deir el-Bahari

Briant Bohleke, Nigel Strudwick

A Label for Opening of the Mouth Implements from the Burial of Senneferi (TT99)

and Remarks on the Ritual

Rosa Maria Bonacasa Carra, Nicola Bonacasa

Nuovi dati sugli edifici termali di Sabratha

EDWARD BROVARSKI

A Fragmentary Carrying Chair Scene in Salt Lake City, Utah

Julia Burdajewicz

Wall Painting Decoration from the North-West Church in Hippos-Sussita

of the Decapolis

Mariusz BURDAJEWICZ

From Pagan Temple to Church in Late Antiquity Palestine. A View from

Hippos-Sussita

MAREK ChlodNicki

Early Dynastic Bead Workshops at the Central Kom of Tell el-Farkha.

Patryk ChudziK, Mariusz Caban

Observations on the Architecture of the Tomb of Horhotep in Western Thebes

Krzysztof M. Cialowicz

New Discoveries at Tell el-Farkha and the Beginnings of the Egyptian State.

Amr EL-TiebI

Four Wooden New Kingdom Female Statuettes in the Egyptian Museum, Cairo 


\section{Naguib KanaWATI}

Ritual Marriage Alliances and Consolidation of Power in Middle Egypt during the Middle Kingdom

Adam Łajtar, Jolanta Mlynarczyk

A Faction Acclamation Incised on a Pithos Found Near the North-West Church at Hippos (Sussita)

Adam ŁaJTAR, Grzegorz OchaŁa

Two Private Prayers in Wall Inscriptions in the Faras Cathedral

Adam Łajtar, Anna Poludnikiewicz

Medicinal Vessels from Tell Atrib (Egypt)

JaCeK Michniewicz, Jolanta MlynarczyK

Petrographic Variability of the Fabrics of Wine Jars from Sha'ar-Ha Amakim as a Reflection of Differences in Their Provenance and Chronology

Iwona ModrzewsKa-PianetTI

Les importations d'amphores Dressel 20 en Gaule Cisalpine

Arthur SEgal

Samaria-Sebaste. Portrait of a polis in the Heart of Samaria 409

JOACHIM ŚLIWA

The Motif of a 'Blind Harper' in an Unexpected Place

MONIKA WIĘCH

Searching for the Kitchen in the Early Roman Phase of the 'Hellenistic' House at Nea Paphos (Cyprus)

Abréviations 
THE VOLUME IS PUBLISHED TO CELEBRATE

THE $60^{\text {TH }}$ ANNIVERSARY

OF THE ESTABLISHMENT OF

THE RESEARCH CENTRE FOR MEDITERRANEAN ARCHAEOLOGY POLISH ACADEMY OF SCIENCES

FOUNDED IN 1956

WHOSE MISSION IS CONTINUED BY

THE INSTITUTE OF MEDITERRANEAN AND ORIENTAL CULTURES

OF THE POLISH ACADEMY OF SCIENCES 